\title{
Effects of fining on phenolic compounds and colour of red wine obtained with addition of increased amounts of grape solid phase in pomace
}

\author{
Vladimir S. Puškaš, Uroš D. Miljić \\ University of Novi Sad, Faculty of Technology, Novi Sad, Serbia
}

\begin{abstract}
The purpose of this work is to study the effect of grape pomace enrichment in solid phase (stems and seeds) on phenolic compounds and colour stability of obtained red wines, before and after use of different fining agents. Results have shown increase in total phenols and flavan-3-ols content after grape solid phase addition. On the other hand, decrease in anthocyanins content has generally been recorded in all wine samples except in wines obtained with addition of $40 \mathrm{~g} / \mathrm{l}$ of seeds during maceration. Stems addition caused decrease in colour intensity while addition of seeds has increased this colour parameter. The use of four fining agents (albumin, gelatine, bentonite and PVPP) has been investigated and compared, especially in terms of their influence on potential stabilization effect of grape solid phase on wine colour. Fined wines tended to have considerably lower anthocyanin and flavan-3-ol levels, especially in the case of gelatine and PVPP treatment (decrease up to 60 and $70 \%$, respectively). In the case of chromatic parameters, the used fining agents caused colour intensity decrease but it is important to emphasize that their values, after fining, were still as high as expected from red wine. This can be explained by the stabilization effect of increased flavan-3-ols content.
\end{abstract}

Keywords: red wine; stems; seeds; fining agents; phenolic compounds; colour.

SCIENTIFIC PAPER

UDC 663.257.3

Hem. Ind. 66 (5) 727-734 (2012)

doi: 10.2298/HEMIND111209018P

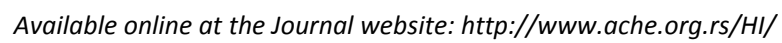

Grapes contain a great amount of different phenolic compounds, which are located in different parts of grape cluster (seeds, pulp, skin and cluster stems), and their types and amount are affected by several factors [1-6]. These compounds, especially anthocyanins and proanthocyanidols, are extracted in the maceration process and they are responsible for the characteristic colour, flavour and astringency of red wine. Seeds, stems and skin are the main source of these compounds in wine [7-9]. Seeds contain about $60 \%$ of total phenolic compounds of grapes, wherein most of these compounds are flavan-3-ol monomers and polymers (proanthocyanidols) [10]. Significant concentrations of tannins are found in cluster stems, of which $40-50 \%$ is polymerized [11]. Flavan-3-ols and tannin extraction from seeds is more intensive with the increase of ethanol content in pomace during vinification, according to their lower solubility in water $[5,12]$. Catechins, as the most widespread in the plant world, are the most important flavan-3-ol derivative. These compounds are found in free form, but can also be esterified, most commonly with gallic acid. In grapes and wine (+)-catechin, (-)-epicatechin, epicatechin-3-0-gallate and their dimers, trimers and oligomers are found

Correspondence: U.D. Miljić, Department of Biotechnology and Pharmaceutical Engeneering, Faculty of Technology, University of Novi Sad, Bulevar Cara Lazara 1, 21000 Novi Sad, Serbia.

E-mail: urosmiljic@yahoo.com

Paper received: 9 December, 2011

Paper accepted: 6 March, 2012
[13-15]. Clarification and stabilization of wine are essential processes of removing haze particles and unstable wine substances, which can cause subsequent instability. The clarified wine should remain clear and the fining process should not have any undesirable effects, such as removal of desired or addition of undesired flavour components [16]. Commonly used fining agents in the wine industry such as bentonite, gelatine, casein, egg albumin and PVPP can lead to considerable decrease in some phenolic compounds [16-18]. However, it has also been reported that phenolic composition and content of wine were not significantly affected by gelatine fining treatments $[19,20]$. Furthermore, it was shown that the use of bentonite plus gelatine as fining agents produced a poor wine colour, while treatment with PVPP resulted in more coloured and less brown wine [21]. Albumin was proven to be an especially efficient fining agent for highly polymerized tannins [16,19]. Previous studies [22,23] emphasized the positive effect of pomace supplementation with grape solid phase on the colour of obtained wines. However, the effects of fining on chromatic parameters of such wines had never been investigated.

The purpose of this research was to investigate the effects of different fining agents on phenolic compounds and colour of red wines obtained after applying different ratios of seeds and stems during the maceration process. 


\section{MATERIALS AND METHODS}

\section{Grape and wines}

The research was carried out on young wines made from the Cabernet Sauvignon grape grown in the experimental vineyard of Faculty of Agriculture in Sremski Karlovci (Novi Sad, Serbia). The grape was hand-harvested at technological maturity in 2009. Grape processing in laboratory conditions was carried out immediately after harvest. Microvinification was performed with $5 \mathrm{~kg}$ of pomace per each experiment. The pomace was treated with $\mathrm{K}_{2} \mathrm{~S}_{2} \mathrm{O}_{5}(200 \mathrm{mg} / \mathrm{kg}$ grape). Alcoholic fermentation was conducted by use of commercial yeast Saccharomyces cerevisiae (Anchor WE372, South Africa), which was rehydrated and inoculated in the pomace $(0.2 \mathrm{~g} / \mathrm{kg}$ pomace). Microvinification (maceration and alcoholic fermentation) was carried out at 28-30 ${ }^{\circ} \mathrm{C}$ during 6 and 9 days after which the pomace was pressed. After 2 days wine was separated from yeast lees, while, concentration of total sulphur dioxide was set at about $100 \mathrm{mg} / \mathrm{L}$ of wine in all samples. The first racking was conducted after one month. After racking, wine is poured into $500 \mathrm{ml}$ glass bottles closed with crown closures. Wine is kept at about $10-12{ }^{\circ} \mathrm{C}$ during two months, after which fining and wine analyses were carried out.

Two series of experiments were performed. The first series of samples (A) were obtained from pomace supplemented with $25\left(A_{1}\right), 50\left(A_{2}\right)$ and $100 \%\left(A_{3}\right)$ of previously separated stems, while the second series $(B)$ is obtained from pomace supplemented with $40\left(B_{1}\right)$, $80\left(B_{2}\right)$ and $120 \mathrm{~g} / \mathrm{L}\left(B_{3}\right)$ of seeds. Control wines $(K)$ were produced from pomace contained original content of seed (40 g/kg grape), while the stem was separated.

\section{Fining}

Fining of obtained wines was performed with following fining agents: gelatine (GELAXINA ORO, Gruppo Vason, Italy), albumin (ALBUCAR, Gruppo Vason, Italy), Na-bentonite (PLUSGRAN, Gruppo Vason, Italy), and PVPP (Gruppo Vason, Italy). After four days, the wines were separated from a precipitate and analysed. The dosage of gelatine, albumin and PVPP used in this study was $0.2 \mathrm{~g} / \mathrm{L}$ of wine, while the dosage of bentonite was $0.75 \mathrm{~g} / \mathrm{L}$ of wine.

\section{Analysis}

Total phenols were analysed by the Folin-Ciocalteu method [24], with gallic acid standard, and results were expressed as gallic acid equivalent (GAE). Chromatic characteristics of wine were determined spectrophotometrically by measuring absorbance at 420, 520 and $620 \mathrm{~nm}$ in a $1 \mathrm{~mm}$ cell in regard to double distilled water [25]. Total anthocyanins were determined by spec- trophotometry at $520 \mathrm{~nm}$, according to the ability of anthocyanins to discolour after addition of $\mathrm{SO}_{2}$ (in the $\mathrm{K}_{2} \mathrm{~S}_{2} \mathrm{O}_{5}$ form) at $\mathrm{pH} 1$ [26]. Total flavan-3-ols content was analysed by the Vanillic method [27] by use of (+)-catechin as a standard.

\section{HPLC Analysis}

The analyses of catechins were carried out in ethyl acetate fraction obtained by using the wine phenolics fractionation procedure [28]. This involves the use of Sep-Pak $\mathrm{C}_{18}$ cartridges (Waters Associate). The fraction was dried under vacuum at $30{ }^{\circ} \mathrm{C}$, dissolved in $50 \%$ methanol $(500 \mu \mathrm{L})$ and stored at $-18{ }^{\circ} \mathrm{C}$ until analysis. The content of phenolic compounds in samples was determined by HPLC on a liquid chromatograph HP 1090 (Hewlett-Packard, USA). A ZORBAX SB-C18 column, $5 \mu \mathrm{m}, 3.0 \mathrm{~mm} \times 250 \mathrm{~mm}$, protected with a ZORBAX SBC18 pre-column, $5 \mu \mathrm{m}, 4.6 \mathrm{~mm} \times 12.5 \mathrm{~mm}$ (Agilent, USA) was used. Detection of separated peaks was performed using a detector with a series diode (Diode Array Detector, DAD) at $277 \mathrm{~nm}$ and absorption spectra of components were recorded in the range of 210 to $400 \mathrm{~nm}$. As a mobile phase solvent system was used: $A-1 \%$ (v/v) glacial acetic acid in water and B - acetonitrile. Separation of components was performed using the following linear gradient: 0-20 $\mathrm{min}, 95-87 \% \mathrm{~A}, 20-30$ $\min , 87 \%$ A, 30-45 $\mathrm{min}, 87-10 \% \mathrm{~A}$ and $45-65 \mathrm{~min}, 10 \%$ A. The column was balanced on the initial conditions, $95 \%$ A, $10 \mathrm{~min}$. The mobile phase flow rate was 0.300 $\mathrm{ml} / \mathrm{min}$. Ten $\mu \mathrm{L}$ of sample solution was injected manually. (+)-Catechin and (-)-epicatechin standards (Fluka $A G$, Switzerland) had been used.

\section{Statistical analysis}

Statistical analyses in the present study were performed using Statistica 10.0 (Statsoft, 2011). Data in tables represents average values of three replications. Statistical significance of differences among average values for samples of varieties or treatments was estimated by analyses of variance (Anova) at the $95 \%$ confidence level. Values detected as significantly different were marked with different letters $(a, b, c$, etc.).

\section{RESULTS AND DISCUSSION}

\section{Effects of pomace enrichment in grape solid phase}

Sample wines made using traditional vinification, obtained from the pomace with an increased content of grape solid phase, were treated by the usual fining agents. The influence of fining with different fining agents on the amount of total phenolic compounds, anthocyanins and flavan-3-ols in wines made after 6 and 9 days of vinification is shown in Table 1.

The enrichment of pomace by grape seeds and stems during maceration clearly affected the total phenols 
Table 1. Total phenols $[\mathrm{g} / \mathrm{L}]$, anthocyanins $[\mathrm{g} / \mathrm{L}]$ and flavan-3-ols $[\mathrm{g} / \mathrm{L}]$ content in wines obtained with addition of supplementary quantities of grape solid phase during 6 and 9 days of maceration, with and without fining. $K$, Control sample; $A_{1}, 25 \%$ of stems; $A_{2}, 50 \%$ of stems; $A_{3}, 100 \%$ of stems; $B_{1}, 40 \mathrm{~g} / \mathrm{L}$ of seeds, $B_{2}, 80 \mathrm{~g} / \mathrm{L}$ of seeds; $B_{3}, 120 \mathrm{~g} / \mathrm{L}$ of seeds; $T_{0}$, without fining; $T_{1}$, albumin; $T_{2}$ gelatine; $T_{3}$, Na-bentonite; $T_{4}$, polyvinylpolypyrolidone (PVPP). Data given in the table present mean values from three replications $(n=3)$; Different letters within the same separated section (combination of effects: type and share of solid phase, fining agents, length of maceration) mean significant differences $(p<0.05)$

\begin{tabular}{|c|c|c|c|c|c|c|c|c|c|c|c|c|c|c|c|c|}
\hline \multirow{2}{*}{$\begin{array}{l}\text { Maceration } \\
\text { duration, days }\end{array}$} & \multirow{2}{*}{ Sample } & \multicolumn{5}{|c|}{ Total phenols } & \multicolumn{5}{|c|}{ Anthocyanins } & \multicolumn{5}{|c|}{ flavan-3-ols } \\
\hline & & $\mathrm{T}_{0}$ & $\mathrm{~T}_{1}$ & $\mathrm{~T}_{2}$ & $\mathrm{~T}_{3}$ & $\mathrm{~T}_{4}$ & $\mathrm{~T}_{0}$ & $\mathrm{~T}_{1}$ & $\mathrm{~T}_{2}$ & $\mathrm{~T}_{3}$ & $\mathrm{~T}_{4}$ & $\mathrm{~T}_{0}$ & $\mathrm{~T}_{1}$ & $\mathrm{~T}_{2}$ & $\mathrm{~T}_{3}$ & $\mathrm{~T}_{4}$ \\
\hline \multirow[t]{8}{*}{6} & K & $1.21^{\mathrm{e}}$ & $1.17^{d}$ & $1.09^{c}$ & $0.94^{\mathrm{a}}$ & $1.12^{\mathrm{d}}$ & $0.27^{h}$ & $0.23^{\mathrm{fg}}$ & $0.19^{b}$ & $0.22^{\mathrm{ef}}$ & $0.16^{\mathrm{a}}$ & $0.16^{c}$ & $0.07^{\mathrm{ab}}$ & $0.06^{\mathrm{a}}$ & $0.09^{b}$ & $0.15^{\mathrm{cd}}$ \\
\hline & A1 & $1.39^{\mathrm{ij}}$ & $1.37^{\mathrm{ij}}$ & $1.35^{\text {ghi }}$ & $1.05^{b}$ & $1.32^{\mathrm{gh}}$ & $0.28^{h}$ & $0.24^{e f}$ & $0.21^{\mathrm{ef}}$ & $0.21^{\text {def }}$ & $0.21^{b c}$ & $0.25^{i}$ & $0.15^{c d}$ & $0.17^{\text {def }}$ & $0.22^{g h}$ & $0.18^{\text {efg }}$ \\
\hline & A2 & $1.43^{k}$ & $1.30^{\mathrm{gh}}$ & $1.38^{\mathrm{ij}}$ & $1.11^{\mathrm{c}}$ & $1.35^{\mathrm{hi}}$ & $0.25^{\mathrm{gh}}$ & $0.20^{\mathrm{cd}}$ & $0.16^{\mathrm{a}}$ & $0.19^{b c d}$ & $0.15^{a}$ & $0.29^{i}$ & $0.19^{\text {cde }}$ & ${ }^{\mathrm{e}} 0.18^{\text {cde }}$ & $0.23^{h}$ & $0.18^{\text {cde }}$ \\
\hline & A3 & $1.56^{\prime}$ & $1.32^{\mathrm{fg}}$ & $1.28^{\mathrm{f}}$ & $1.25^{f}$ & $1.41^{\mathrm{jk}}$ & $0.24^{\mathrm{gh}}$ & $0.20^{\text {cd }}$ & $0.16^{\mathrm{a}}$ & $0.18^{\mathrm{b}}$ & $0.15^{\mathrm{a}}$ & $0.48^{\mathrm{j}}$ & $0.25^{i}$ & $0.22^{\mathrm{fg}}$ & $0.28^{i}$ & $0.19^{\text {cde }}$ \\
\hline & $\mathrm{K}$ & $1.21^{d}$ & $1.17^{c}$ & $1.09^{b}$ & $0.94^{a}$ & $1.12^{\mathrm{c}}$ & $0.27^{f}$ & $0.23^{e}$ & $0.19^{b c}$ & $0.22^{\mathrm{de}}$ & $0.16^{b}$ & $0.16^{\text {cde }}$ & ${ }^{\mathrm{e}} 0.07^{\mathrm{ab}}$ & $0.06^{a}$ & $0.09^{b}$ & $0.15^{\text {cde }}$ \\
\hline & B1 & $1.52^{\mathrm{h}}$ & $1.29^{\mathrm{e}}$ & $1.38^{f}$ & $1.25^{\mathrm{de}}$ & $1.46^{\mathrm{g}}$ & $0.29^{\mathrm{g}}$ & $0.25^{\mathrm{e}}$ & $0.24^{\mathrm{e}}$ & $0.25^{\mathrm{e}}$ & $0.22^{\mathrm{e}}$ & $0.29^{\mathrm{gh}}$ & $0.19^{\mathrm{de}}$ & $0.13^{\mathrm{cd}}$ & $0.27^{\mathrm{fg}}$ & $0.13^{c}$ \\
\hline & B2 & $1.77^{j}$ & $1.07^{b}$ & $1.68^{i}$ & $1.22^{\mathrm{de}}$ & $1.55^{\mathrm{h}}$ & $0.25^{\mathrm{e}}$ & $0.22^{\mathrm{de}}$ & $0.18^{b c}$ & $0.23^{\mathrm{e}}$ & $0.19^{\text {cd }}$ & $0.33^{i}$ & $0.25^{f}$ & $0.19^{\mathrm{de}}$ & $0.30^{\mathrm{hi}}$ & $0.19^{e}$ \\
\hline & B3 & $3.61^{\circ}$ & $2.69^{\mathrm{k}}$ & $3.20^{n}$ & $2.82^{\prime}$ & $3.13^{\mathrm{m}}$ & $0.23^{\mathrm{e}}$ & $0.18^{b c}$ & $0.11^{\mathrm{a}}$ & $0.18^{b c d}$ & $0.09^{a}$ & $1.15^{\mathrm{m}}$ & $0.65^{k}$ & $0.53^{j}$ & $1.04^{\prime}$ & $0.61^{k}$ \\
\hline \multirow[t]{8}{*}{9} & K & $1.55^{\text {gh }}$ & $1.48^{\mathrm{de}}$ & $1.51^{\mathrm{efg}}$ & $1.43^{\mathrm{cd}}$ & $1.51^{\mathrm{efg}}$ & $0.34^{k}$ & $0.26^{i}$ & $0.22^{\text {gh }}$ & $0.25^{\mathrm{hi}}$ & $0.20^{\text {efg }}$ & $0.26^{\text {ef }}$ & $0.24^{\text {cde }}$ & $0.15^{\mathrm{a}}$ & $0.25^{\text {ef }}$ & $0.19^{\mathrm{ab}}$ \\
\hline & A1 & $1.58^{\mathrm{hi}}$ & $1.38^{b c}$ & $1.56^{\mathrm{gh}}$ & $1.35^{\mathrm{ab}}$ & $1.47^{\text {def }}$ & $0.34^{k}$ & $0.30^{j}$ & $0.19^{\text {def }}$ & $0.28^{i}$ & $0.21^{\mathrm{fg}}$ & $0.29^{\mathrm{fg}}$ & $0.27^{\mathrm{ef}}$ & $0.17^{\mathrm{ab}}$ & $0.25^{\mathrm{de}}$ & $0.14^{\mathrm{a}}$ \\
\hline & A2 & $1.62^{i}$ & $1.35^{\mathrm{ab}}$ & $1.49^{\mathrm{de}}$ & $1.32^{\mathrm{a}}$ & $1.47^{\text {def }}$ & $0.25^{h i}$ & $0.19^{\text {efg }}$ & $0.14^{d}$ & $0.18^{\mathrm{de}}$ & $0.16^{d}$ & $0.33^{\mathrm{gh}}$ & $0.28^{e f}$ & $0.17^{\mathrm{ab}}$ & $0.20^{b c}$ & $0.15^{\mathrm{a}}$ \\
\hline & A3 & $1.73^{\mathrm{j}}$ & $1.52^{\mathrm{fgh}}$ & $1.63^{i}$ & $1.62^{i}$ & $1.65^{i}$ & $0.12^{c}$ & $0.09^{a b}$ & $0.05^{\mathrm{a}}$ & $0.10^{b c}$ & $0.07^{a}$ & $0.52^{i}$ & $0.36^{\mathrm{h}}$ & $0.26^{\mathrm{ef}}$ & $0.32^{\mathrm{gh}}$ & $0.20^{\text {bcd }}$ \\
\hline & K & $1.55^{c}$ & $1.48^{\mathrm{a}}$ & $1.51^{b}$ & $1.43^{\mathrm{a}}$ & $1.51^{b}$ & $0.34^{j}$ & $0.26^{i}$ & $0.22^{\mathrm{fgh}}$ & $0.25^{\mathrm{hi}}$ & $0.20^{\text {def }}$ & $0.26^{\text {gh }}$ & $0.24^{\mathrm{fg}}$ & $0.15^{a b c}$ & $0.25^{\mathrm{gh}}$ & $0.19^{\text {cde }}$ \\
\hline & B1 & $1.81^{\mathrm{g}}$ & $1.60^{d}$ & $1.69^{\mathrm{e}}$ & $1.62^{d}$ & $1.75^{f}$ & $0.42^{k}$ & $0.33^{j}$ & $0.25^{\mathrm{hi}}$ & $0.31^{j}$ & $0.23^{\text {gh }}$ & $0.44^{j}$ & $0.20^{\mathrm{de}}$ & $0.13^{\mathrm{a}}$ & $0.36^{i}$ & $0.14^{\mathrm{ab}}$ \\
\hline & B2 & $2.36^{j}$ & $1.81^{\mathrm{g}}$ & $2.01^{i}$ & $1.84^{\mathrm{g}}$ & $1.94^{h}$ & $0.24^{\mathrm{ghi}}$ & $0.19^{\mathrm{def}}$ & $0.10^{\mathrm{ab}}$ & $0.19^{\text {def }}$ & $0.17^{\text {de }}$ & $0.62^{k}$ & $0.29^{h}$ & $0.17^{b c d}$ & $0.35^{i}$ & $0.23^{\text {efg }}$ \\
\hline & B3 & $3.93^{\mathrm{m}}$ & $3.05^{1}$ & $2.85^{\mathrm{k}}$ & $3.06^{\prime}$ & $3.08^{\prime}$ & $0.21^{\text {efg }}$ & ${ }^{g} 0.16^{c d}$ & $0.08^{a}$ & $0.18^{\text {def }}$ & $0.13^{b c}$ & $1.27^{n}$ & $0.79^{\mathrm{m}}$ & $0.43^{j}$ & $0.68^{\prime}$ & $0.45^{j}$ \\
\hline
\end{tabular}

content in obtained wines. As expected, the content of total phenolic compounds is increased by extending the duration of maceration, from 6 to 9 days, in all samples. This was also detected by other researchers $[22,23]$. Addition of $100 \%$ of previously removed stems resulted in increased total phenols content by $30 \%$ comparing with control wine after 6 days of maceration. Furthermore, addition of 80 and $120 \mathrm{~g}$ seed/kg grape pomace caused 0.5 and 2 times higher content of total phenolic compounds in comparison to control wine after 6 days of maceration and a similar trend is obtained also for 9 days of maceration. In wines obtained with supplementation by grape stems, prolonged maceration caused increase in total phenols content in average by $15 \%$, while addition of seeds has caused enhancement by $20 \%$. Content of flavan-3-ols showed a similar increase trend as total phenols, and their share in total phenols was up to $35 \%$. Generally, addition of seeds caused relatively higher content of flavan-3-ols then addition of stems. Previous studies showed flavan-3-ol monomers as main constituents of grape seed phenolic compounds [29]. Extension of maceration led to slightly increase of flavan-3-ols content in all wines. The results obtained by HPLC analysis (Table 2) showed that stems and seeds contribute to higher concentrations of catechins. The presented results represent average values of HPLC analysis. In control wine, the concentration of $(+)$-catechin was $27.5 \mathrm{mg} / \mathrm{L}$ and after addition of $100 \%$ stems, $48.9 \mathrm{mg} / \mathrm{L}$, while the addition of 80 and $120 \mathrm{~g}$ seed/kg grape pomace caused increase of (+)-catechin to 69 and $105 \mathrm{mg} / \mathrm{L}$, respectively. On the other hand, the content of (-)-epicatechin was $42.7 \mathrm{mg} / \mathrm{L}$ in control wine and $65 \mathrm{mg} / \mathrm{L}$ after $100 \%$ stems addition. (-)-epicatechin content in wines obtained with addition of 80 and $120 \mathrm{~g}$ seed/kg pomace were 93 and $129 \mathrm{mg} / \mathrm{L}$, respectively. These results are comparable with those of Fuleki et al. [29] who found that (-)-epicatechin content in grape seed extracts is higher than (+)-catechin. The influence of prolonged maceration on the sum of $(+)$-catechin and (-)-epicatechin was expressed through the $15 \%$ increase after addition of seeds while in wines obtained with addition of stems the changes in catechins content were less pronounced.

From the obtained results it can be seen that addition of seeds in lower amounts ( $40 \mathrm{~g} / \mathrm{kg}$ of pomace) led to significant $(p<0.05)$ increase in anthocyanins content. Further increase in seed share in pomace $\left(B_{2}\right.$ and $B_{3}$ ) caused considerable $(p<0.05)$ decrease in the content of this parameter. Addition of stems in pomace generally caused decrease in anthocyanins content. Furthermore, decrease in anthocyanins content in wines produced with supplementary quantities of grape solid phase was more expressed after 9 day long maceration process while after 6 days of maceration this trend was insignificant $(p>0.05)$. Similar results were obtained in previous experiments $[21,23,30]$. This can be explained 
Table 2. (+)-Catechin and (-)-epicatechin content in wines obtained with addition of supplementary quantities of grape solid phase during 6 and 9 days of maceration, with and without fining. $K$, Control sample; $A_{1}, 25 \%$ of stems; $A_{2}, 50 \%$ of stems; $A_{3}, 100 \%$ of stems; $B_{1}, 40 \mathrm{~g} / \mathrm{L}$ of seeds, $B_{2}, 80 \mathrm{~g} / \mathrm{L}$ of seeds; $B_{3}, 120 \mathrm{~g} / \mathrm{L}$ of seeds; $T_{0}$, without fining; $T_{1}$, albumin; $T_{2}$, gelatine; $T_{3}$, Na-bentonite; $T_{4}$, polyvinylpolypyrolidone (PVPP). Data given in the table present mean values from three replications $(n=3)$; Different letters within the same separated section (combination of effects: type and share of solid phase, fining agents, length of maceration) mean significant differences $(p<0.05)$

\begin{tabular}{|c|c|c|c|c|c|c|c|c|c|c|c|}
\hline \multirow{2}{*}{ Maceration duration, days } & \multirow{2}{*}{ Sample } & \multicolumn{5}{|c|}{$(+)$-Catechin } & \multicolumn{5}{|c|}{ (-)-Epicatechin } \\
\hline & & $\mathrm{T}_{0}$ & $\mathrm{~T}_{1}$ & $\mathrm{~T}_{2}$ & $\mathrm{~T}_{3}$ & $\mathrm{~T}_{4}$ & $\mathrm{~T}_{0}$ & $\mathrm{~T}_{1}$ & $\mathrm{~T}_{2}$ & $T_{3}$ & $\mathrm{~T}_{4}$ \\
\hline \multirow[t]{8}{*}{6} & K & $27.5^{i}$ & $19.8^{\mathrm{b}}$ & $17.9^{\mathrm{a}}$ & $23.7^{f}$ & $21.2^{c}$ & $42.7^{j}$ & $29.8^{c}$ & $26.1^{\mathrm{a}}$ & $35.1^{f}$ & $27.4^{b}$ \\
\hline & $A_{1}$ & $30.7^{\mathrm{k}}$ & $22.5^{\mathrm{e}}$ & $19.7^{\mathrm{b}}$ & $25.1^{\mathrm{h}}$ & $22.1^{\mathrm{d}}$ & $47.7^{\mathrm{m}}$ & $36.7^{\mathrm{h}}$ & $35.8^{\mathrm{g}}$ & $38.4^{i}$ & $35^{f}$ \\
\hline & $\mathrm{A}_{2}$ & $36.7^{\circ}$ & $27.9^{i}$ & $24.7^{\mathrm{g}}$ & $28.7^{j}$ & $23.8^{f}$ & $52.3^{p}$ & $35^{f}$ & $31^{d}$ & $44.8^{\mathrm{k}}$ & $32.2^{\mathrm{e}}$ \\
\hline & $\mathrm{A}_{3}$ & $48.9^{9}$ & $34.3^{\mathrm{m}}$ & $32.1^{1}$ & $40.1^{p}$ & $34.9^{n}$ & $65^{9}$ & $48^{m}$ & $46.7^{\prime}$ & $50.1^{\circ}$ & $48.8^{n}$ \\
\hline & K & $27.5^{\mathrm{e}}$ & $19.8^{b}$ & $17.9^{\mathrm{a}}$ & $23.7^{d}$ & $21.2^{c}$ & $42.7^{f}$ & $29.8^{c}$ & $26.1^{\mathrm{a}}$ & $35.1^{d}$ & $27.4^{b}$ \\
\hline & $\mathrm{B}_{1}$ & $41.3^{\mathrm{i}}$ & $31.2^{\mathrm{g}}$ & $28.9^{f}$ & $32.7^{\mathrm{h}}$ & $28.5^{f}$ & $61.1^{i}$ & $45.2^{\mathrm{g}}$ & $41.3^{\mathrm{e}}$ & $50.3^{h}$ & $42.9^{f}$ \\
\hline & $\mathrm{B}_{2}$ & $69^{n}$ & $50.1^{1}$ & $44.7^{\mathrm{j}}$ & $52^{m}$ & $48.9^{k}$ & $93^{n}$ & $68.4^{\prime}$ & $67.5^{\mathrm{k}}$ & $71.8^{\mathrm{m}}$ & $66.9^{\mathrm{j}}$ \\
\hline & $\mathrm{B}_{3}$ & $105^{\mathrm{s}}$ & $78^{p}$ & $73^{p}$ & $81.1^{r}$ & $71.8^{\circ}$ & $129^{5}$ & $101.2^{q}$ & $94^{\circ}$ & $105^{r}$ & $95.2^{p}$ \\
\hline \multirow[t]{8}{*}{9} & $\mathrm{~K}$ & $29.3^{j}$ & $18.9^{b}$ & $21.2^{d}$ & $22.8^{f}$ & $22.1^{\mathrm{e}}$ & $43.3^{i}$ & $31.2^{c}$ & $28.4^{a}$ & $36^{f}$ & $28.7^{\mathrm{a}}$ \\
\hline & $A_{1}$ & $29.9^{k}$ & $20^{c}$ & $18.1^{\mathrm{a}}$ & $24^{\mathrm{g}}$ & $19.7^{c}$ & $49.9^{1}$ & $34.1^{d}$ & $30.1^{b}$ & $40.2^{\mathrm{h}}$ & $33.7^{d}$ \\
\hline & $A_{2}$ & $38.7^{p}$ & $26.1^{h}$ & $26.9^{i}$ & $31^{\prime}$ & $29.9^{k}$ & $52.4^{m}$ & $35.1^{\mathrm{e}}$ & $34.9^{\mathrm{e}}$ & $36.9^{\mathrm{g}}$ & $35.8^{f}$ \\
\hline & $\mathrm{A}_{3}$ & $52.9^{r}$ & $37.1^{\circ}$ & $34.7^{\mathrm{m}}$ & $42.1^{q}$ & $35.8^{n}$ & $70.3^{\circ}$ & $50^{\prime}$ & $47.2^{j}$ & $55.2^{n}$ & $49.1^{k}$ \\
\hline & $\mathrm{K}$ & $29.3^{\mathrm{e}}$ & $18.9^{\mathrm{a}}$ & $21.2^{b}$ & $22.8^{d}$ & $22.1^{c}$ & $43.3^{f}$ & $31.2^{c}$ & $28^{a}$ & $36^{d}$ & $28.7^{b}$ \\
\hline & $\mathrm{B}_{1}$ & $43.9^{i}$ & $33.4^{h}$ & $30.1^{f}$ & $33.8^{h}$ & $32.8^{\mathrm{g}}$ & $66.8^{j}$ & $48.6^{\mathrm{h}}$ & $41.2^{\mathrm{e}}$ & $50.2^{i}$ & $46.3^{\mathrm{g}}$ \\
\hline & $B_{2}$ & $79.3^{\circ}$ & $53.1^{\mathrm{j}}$ & $53.5^{j}$ & $63^{\prime}$ & $55.9^{k}$ & $110^{\mathrm{p}}$ & $79.5^{1}$ & $75.3^{k}$ & $88^{m}$ & $75^{\mathrm{k}}$ \\
\hline & $\mathrm{B}_{3}$ & $118^{s}$ & $82.2^{q}$ & $76.8^{m}$ & $92^{r}$ & $78.2^{n}$ & $147.6^{r}$ & $103.4^{\circ}$ & $103^{\circ}$ & $112^{q}$ & $101.4^{n}$ \\
\hline
\end{tabular}

by the fact that content of free anthocyanins usually increases in the early stages of maceration and after two-seven days from beginning of maceration it starts to decrease for several reasons [31,32]. It should be mentioned that share of anthocyanins in the total phenols was 24 and $21 \%$ after 6 and 9 days of maceration, respectively.

In Table 3, the influence of fining treatment on chromatic characteristics of obtained wines is shown. The addition of seeds in pomace caused higher colour intensity in wines than addition of stems. Furthermore, stems addition has caused decrease in colour intensity and, on the other hand, addition of seeds has increased this colour parameter. The increase in colour intensity, despite the decline of anthocyanins content, can be explained by the increase of flavan-3-ols from seeds, which are responsible for increased absorbance at 420 $\mathrm{nm}$ (yellow colour), but also for stabilization of red wine colour. Obtained results can imply that stems have been causing much greater adsorption of coloured compounds than grape seeds and that fact can explain the previously mentioned decrease in colour intensity after addition of stems in pomace. With regard to hue, an increasing trend can be noticed in obtained wines. The highest values were determined in wines obtained with addition of stems, especially in wines with $100 \%$ of stems after 9 days of maceration (0.686). In most cases, these results may be explained by the decrease of content of anthocyanins (red colour constituents) due to polymerization reactions, interactions with other phenolic compounds, adsorption of stems and, also, length of maceration [16]. On the other hand, previously mentioned increase of flavan-3-ols, also contributes to hue increase. It was reported that use of whole clusters ( $100 \%$ of stems) in wine production did not have significant influence on colorimetric parameters (colour intensity and hue) during the first 7 days of maceration, but also that dramatic changes had occurred after 14 days of maceration [22].

\section{Effects of fining agents}

The use of fining agents should have insignificant effect on aromatic and flavour compounds of wine and it should allow the wine to preserve clarity and characteristic flavour, colour and bouquet as long as necessary before consummation.

The impact of fining agents on the changes in phenolic compounds in wines obtained after addition of supplementary quantities of seeds and stem is given in Table 1. As already mentioned, in the winemaking protocols 6 and 9 days maceration was applied.

The largest amounts of phenolic compounds from obtained wines were removed by use of albumin and bentonite. Albumin treatment has caused a considerable ( $p<0.05$ ) decrease (from 15 to $26 \%$ ) in total phenols especially in wines obtained with addition of seeds. 
Table 3. Colour intensity and hue values of wines obtained with addition of supplementary quantities of grape solid phase ${ }^{a}$ during 6 and 9 days of maceration, with and without fining. $K$, Control sample; $A_{1}, 25 \%$ of stems; $A_{2}, 50 \%$ of stems; $A_{3}, 100 \%$ of stems; $B_{1}$ $40 \mathrm{~g} / \mathrm{L}$ of seeds, $B_{2}, 80 \mathrm{~g} / \mathrm{L}$ of seeds; $B_{3}, 120 \mathrm{~g} / \mathrm{L}$ of seeds; $T_{0}$, without fining; $T_{1}$, albumin; $T_{2}$, gelatine; $T_{3}, N a$-bentonite; $T_{4}$, polyvinylpolypyrolidone (PVPP). Data given in the table present mean values from three replications $(n=3)$; Different letters within the same separated section (combination of effects: type and share of solid phase, fining agents, length of maceration) mean significant differences $(p<0.05)$

\begin{tabular}{|c|c|c|c|c|c|c|c|c|c|c|c|}
\hline \multirow{2}{*}{ Maceration duration, days } & \multirow{2}{*}{ Sample } & \multicolumn{5}{|c|}{ Colour intensity } & \multicolumn{5}{|c|}{ Hue } \\
\hline & & $\mathrm{T}_{0}$ & $\mathrm{~T}_{1}$ & $\mathrm{~T}_{0}$ & $\mathrm{~T}_{1}$ & $\mathrm{~T}_{0}$ & $\mathrm{~T}_{1}$ & $\mathrm{~T}_{0}$ & $\mathrm{~T}_{1}$ & $\mathrm{~T}_{0}$ & $\mathrm{~T}_{1}$ \\
\hline \multirow[t]{8}{*}{6} & K & $1.034^{\prime}$ & $1.013^{k}$ & $1.034^{\prime}$ & $1.013^{\mathrm{k}}$ & $1.034^{\prime}$ & $1.013^{\mathrm{k}}$ & $1.034^{\prime}$ & $1.013^{\mathrm{k}}$ & $1.034^{\prime}$ & $1.013^{\mathrm{k}}$ \\
\hline & $A_{1}$ & $0.988^{j}$ & $0.972^{\mathrm{ij}}$ & $0.988^{j}$ & $0.972^{\mathrm{ij}}$ & $0.988^{j}$ & $0.972^{i j}$ & $0.988^{j}$ & $0.972^{i j}$ & $0.988^{j}$ & $0.972^{\mathrm{ij}}$ \\
\hline & $\mathrm{A}_{2}$ & $1.067^{\mathrm{m}}$ & $1.022^{\mathrm{kl}}$ & $1.067^{\mathrm{m}}$ & $1.022^{\mathrm{kl}}$ & $1.067^{\mathrm{m}}$ & $1.022^{\mathrm{kl}}$ & $1.067^{\mathrm{m}}$ & $1.022^{\mathrm{kl}}$ & $1.067^{\mathrm{m}}$ & $1.022^{\mathrm{kl}}$ \\
\hline & $\mathrm{A}_{3}$ & $0.854^{\mathrm{e}}$ & $0.776^{\mathrm{b}}$ & $0.854^{\mathrm{e}}$ & $0.776^{\mathrm{b}}$ & $0.854^{\mathrm{e}}$ & $0.776^{b}$ & $0.854^{\mathrm{e}}$ & $0.776^{b}$ & $0.854^{\mathrm{e}}$ & $0.776^{\mathrm{b}}$ \\
\hline & K & $1.034^{\mathrm{e}}$ & $1.013^{\mathrm{d}}$ & $1.034^{\mathrm{e}}$ & $1.013^{d}$ & $1.034^{\mathrm{e}}$ & $1.013^{d}$ & $1.034^{\mathrm{e}}$ & $1.013^{d}$ & $1.034^{\mathrm{e}}$ & $1.013^{d}$ \\
\hline & $\mathrm{B}_{1}$ & $1.111^{\mathrm{h}}$ & $1.052^{f}$ & $1.111^{\mathrm{h}}$ & $1.052^{f}$ & $1.111^{\mathrm{h}}$ & $1.052^{f}$ & $1.111^{\mathrm{h}}$ & $1.052^{f}$ & $1.111^{\mathrm{h}}$ & $1.052^{f}$ \\
\hline & $\mathrm{B}_{2}$ & $1.194^{\prime}$ & $1.180^{k}$ & $1.194^{\prime}$ & $1.180^{k}$ & $1.194^{\prime}$ & $1.180^{k}$ & $1.194^{\prime}$ & $1.180^{k}$ & $1.194^{\prime}$ & $1.180^{k}$ \\
\hline & $\mathrm{B}_{3}$ & $1.321^{q}$ & $1.312^{\mathrm{p}}$ & $1.321^{\mathrm{q}}$ & $1.312^{p}$ & $1.321^{q}$ & $1.312^{p}$ & $1.321^{\mathrm{q}}$ & $1.312^{p}$ & $1.321^{q}$ & $1.312^{\mathrm{p}}$ \\
\hline \multirow[t]{8}{*}{9} & $\mathrm{~K}$ & $1.058^{n}$ & $0.946^{j}$ & $1.058^{n}$ & $0.946^{j}$ & $1.058^{n}$ & $0.946^{j}$ & $1.058^{n}$ & $0.946^{j}$ & $1.058^{n}$ & $0.946^{j}$ \\
\hline & $A_{1}$ & $0.985^{\prime}$ & $0.929^{h}$ & $0.985^{\prime}$ & $0.929^{h}$ & $0.985^{\prime}$ & $0.929^{h}$ & $0.985^{\prime}$ & $0.929^{h}$ & $0.985^{1}$ & $0.929^{h}$ \\
\hline & $A_{2}$ & $0.941^{i}$ & $0.876^{d}$ & $0.941^{i}$ & $0.876^{d}$ & $0.941^{i}$ & $0.876^{d}$ & $0.941^{i}$ & $0.876^{d}$ & $0.941^{i}$ & $0.876^{d}$ \\
\hline & $A_{3}$ & $0.913^{\mathrm{g}}$ & $0.895^{\mathrm{e}}$ & $0.913^{g}$ & $0.895^{\mathrm{e}}$ & $0.913^{g}$ & $0.895^{\mathrm{e}}$ & $0.913^{\mathrm{g}}$ & $0.895^{\mathrm{e}}$ & $0.913^{g}$ & $0.895^{\mathrm{e}}$ \\
\hline & $\mathrm{K}$ & $1.058^{\mathrm{e}}$ & $0.946^{b}$ & $1.058^{\mathrm{e}}$ & $0.946^{b}$ & $1.058^{\mathrm{e}}$ & $0.946^{b}$ & $1.058^{\mathrm{e}}$ & $0.946^{b}$ & $1.058^{\mathrm{e}}$ & $0.946^{b}$ \\
\hline & $\mathrm{B}_{1}$ & $1.225^{\mathrm{i}}$ & $1.087^{f}$ & $1.225^{i}$ & $1.087^{f}$ & $1.225^{i}$ & $1.087^{f}$ & $1.225^{i}$ & $1.087^{f}$ & $1.225^{i}$ & $1.087^{f}$ \\
\hline & $B_{2}$ & $1.254^{\mathrm{j}}$ & $1.236^{i}$ & $1.254^{\mathrm{j}}$ & $1.236^{i}$ & $1.254^{\mathrm{j}}$ & $1.236^{i}$ & $1.254^{\mathrm{j}}$ & $1.236^{i}$ & $1.254^{\mathrm{j}}$ & $1.236^{i}$ \\
\hline & $\mathrm{B}_{3}$ & $1.360^{\mathrm{m}}$ & $1.352^{\mathrm{m}}$ & $1.360^{\mathrm{m}}$ & $1.352^{\mathrm{m}}$ & $1.360^{\mathrm{m}}$ & $1.352^{\mathrm{m}}$ & $1.360^{\mathrm{m}}$ & $1.352^{\mathrm{m}}$ & $1.360^{\mathrm{m}}$ & $1.352^{\mathrm{m}}$ \\
\hline
\end{tabular}

In wines produced with stem addition, the decrease was up to $15 \%$. Fining with bentonite $(0.75 \mathrm{~g} / \mathrm{L})$ resulted in decrease of total phenols by $14-24 \%$. Previous reports of bentonite use as a fining agent $[18,33]$ showed that concentration of $1 \mathrm{~g} / \mathrm{L}$ can cause a decrease in total phenols for up to $40 \%$. Major drop in phenolic compounds content has been reported in wines which were more enriched in grape seeds during vinification $\left(B_{3}\right)$. This can be explained by the fact that addition of $120 \mathrm{~g} / \mathrm{l}$ of seeds in pomace led to extraction of greater amounts of flavan-3-ols which, in such large quantities, partially existed in less polymerized and less stable forms. These forms were easily removed by application of all fining agents. Treatments with gelatine and PVPP had lower impact on total phenols, and removal was below $12 \%$ in most of studied wines. Fining treatments on obtained wines were not influenced by the length of maceration.

The used fining agents had significant $(p<0.05)$ influence on anthocyanins content in all the wines studied. Wines fined with gelatine and PVPP suffered major reduction in anthocyanins content, especially wines obtained after 9 days maceration. Gelatine treatment caused the anthocyanin decrease by 25 to $35 \%$ in the case of 6 days maceration meanwhile, in wines produced after 9 days maceration a decrease by 45 to even $60 \%$ was recorded. PVPP promoted a similar fall of these compounds. A possible explanation can be found in the fact that more significant flavan-3-ols extraction from grape solid phase is starting after the sixth day of maceration and that a certain portion of anthocyanins was additionally removed after complex binding with flavan-3-ols [16]. It can be also seen that removal of anthocyanins is more intensive in wines obtained after supplementation of pomace with greater amounts of grape solid phase. High decrease in free anthocyanins (even to 74.1\%) was shown when gelatine was used in dosage of $0.4 \mathrm{~g} / \mathrm{L}$ [33]. A similar decreasing trend was noticed after treatment with other fining agents. The lowest decrease of anthocyanins content was obtained using albumin (10-25\%).

Flavan-3-ols content was significantly $(p<0.05)$ decreased after fining. The decrease from about 35 to $70 \%$ has been achieved. Particularly strong removal effect was noted with use of gelatine and PVPP (45$-55 \%$, in average). The treatment with these fining agents caused the greatest impact on the wines that had had the highest content of flavan-3-ols before fining. It can be noticed that in wines obtained with addition of $120 \mathrm{~g}$ seed $/ \mathrm{kg}$ grape pomace and fined with gelatine and PVPP, flavan-3-ols content was 2-3 times lower than in the unfined control wine. Even after such a significant decrease in the flavan-3-ols content after fining, their amounts are still much higher than in control wines. It should also be mentioned that prolonged maceration has led to even higher decrease in their 
content (even by 70\%). HPLC analyses of wines, after fining procedure, gave information about catechins content and their stability (Table 2). All applied fining agents showed similar results. Decrease in (+)-catechin content was $30 \%$, and decrease in (-)-epicatechin was $35 \%$, in average. Bentonite showed lower impact on total flavan-3-ols content (decrease from about 15 to $40 \%$ ) and also on catechins content (decrease from 19 to $25 \%)$.

The influence of fining agents on colour intensity and hue is presented in Table 3. The colour intensity of fined wines was generally lower than before fining while fining treatments have been causing increase in colour hue. In addition to this, the intensity of yellow colour (absorbance at $420 \mathrm{~nm}$ ) increased, while the intensity of red and blue colour (absorbance at 520 and $620 \mathrm{~nm}$ ) decreased (results are not shown). The greatest impact on colour intensity was caused by use of bentonite (decrease from about 7 to $17 \%$ ). It is important to emphasize the fact that use of bentonite also provides the highest colour hue (increase for about $10 \%)$. PVPP caused lower intensity changes in colour intensity (5\% decrease, in average) while some previous reports indicated that PVPP was the agent that promoted significant fall of anthocyanins and colour intensity [17,34]. It was expected that increased content of flavan-3-ols (caused by enrichment in solid phase) should protect anthocyanins and colour intensity in a way to contribute to their stability $[16,33]$. This study has shown stabilization effect of flavan-3-ols extracted from grape seeds on chromatic characteristics whose values after fining are still as high as expected from red wine. Addition of grape stems had caused decrease in colour intensity and this parameter was further reduced after fining treatment.

\section{CONCLUSION}

The enrichment of pomace by grape seeds and stems during maceration has caused a considerable increase in the content of phenolic compounds of red wines (even two times higher content of total phenols in comparison to control wine). Furthermore, content of total phenols was increased (by about 15-20\%) by extending the duration of maceration, from 6 to 9 days, in all samples. The share of flavan-3-ols in total phenols was up to $35 \%$. Generally, addition of seeds caused relatively higher content of flavan-3-ols then addition of stems. Results have also showed that stems and seeds have been causing a progressive increase in the content of catechins, especially (-)-epicatechin.

The colour of red wine was affected by the addition of supplementary quantities of seeds and stems. The increase of colour intensity and hue, despite the decline of anthocyanins content, was caused by the increase of flavan-3-ols, originating from added grape seeds, and their stabilization effect. Addition of stems in pomace reduced colour intensity of final wines while colour hue was increased.

Treatment with applied fining agents has caused considerable $(p<0.05)$ decrease in phenolic compounds. On the other hand, fining had different effects on chromatic characteristics. Colour intensity was decreased while hue was increased after fining. Gelatine and PVPP had the greatest impact on anthocyanins and flavan-3-ols content (decrease up to 70\%) after prolonged maceration while bentonite has caused the most significant decrease (7-17\%) in colour intensity. Stabilization effect of supplementary quantities of flavan-3-ols from seeds on red wine colour has been noticed in fined wines whose colour intensity stayed as high as expected from red wine, meanwhile hue was increased comparing to the colour hue before fining. Addition of stems did not have significant stabilization effect on wine colour after fining as addition of seeds, and it has even caused decrease in colour intensity.

\section{Acknowledgments}

The authors appreciate financial support from the Ministry of Education, Science and Technological Development of the Republic of Serbia (Project TR-31002).

\section{REFERENCES}

[1] J.J. Macheix, A. Fleuriet, J. Billot, Fruit Phenolics, CRC press: Boca Raton, FI. 1990.

[2] S. Perez-Magarino, M.L. Gonzalez-San Jose, Evolution of flavanols, anthocyanins andtheir derivatives during the aging of red wines elaborated from grapes harvested at different stages of ripening, J. Agric. Food Chem. 52 (2004) 1181-1189.

[3] E. Retali, Prefermentation cold maceration: application to Nielluccio wines, Revue Française d'Enologie 209 (2004) 16-18.

[4] M.R. Salinas, J. Garijo, F. Pardo, A. Zalacain, G.L. Alonso, Colour, polyphenol and aroma compounds in rose wines after prefermentative maceration and enzymatic treatments, Am. J. Enol. Vitic. 54(3) (2003) 195-202.

[5] V. Ivanova, B. Vojnoski, M. Stefova, Effect of winemaking treatment and wine aging on phenolic content in Vranec wines, J. Food Sci. Technol. 49(2) (2012) 161-172 .

[6] J. Vichapong, Y. Santaladchaiyakit, R. Burakham, S. Srijaranai, Cloud-point extraction and reversed-phase high performance liquid chromatography for analysis of phenolic compounds and their antioxidant activity in Thai local wines, J. Food Sci. Technol. (2011), DOI 10.1007/ /s13197-011-0556-0

[7] J.M. Souquet, B. Labarbe, C. Le Guerneve, V. Cheynier, M. Moutounet, Phenolic composition of grape stems, J. Agric. Food Chem. 48 (2000) 1076-1080.

[8] Y. Yilmaz, R.T. Toledo, Major flavonoids in grape seeds and skins: Antioxidant capacity of catechin, epicatechin, and gallic acid, J. Agric. Food Chem. 52 (2004) 255-260. 
[9] R. Canals, M.C. Llaudy, J. Valls, J.M. Canals, F. Zamora, Influence of ethanol concentration on the extraction of color and phenolic compounds from the skin and seeds of Tempranillo grapes at different stages of ripening, J. Agric. Food Chem. 53 (2005) 4019-4025.

[10] M.O. Downey, J.S. Harvey, S.P. Robinson, Analysis of tannins in seeds and skins of Shiraz grapes throughout berry development, Aust J. Grape Wine Res. 9 (2003) 15-27.

[11] K. Kantz, V.L. Singleton, Isolation and determination of polymeric polyphenols in wines using sephandex LH-20, Am. J. Enol. Vitic. 42 (1991) 309-315.

[12] R. Canals, M.C. Llaudy, J. Valls, J.M. Canals, Influence of ethanol concentration on the extraction of color and phenolic compounds from the skin and seeds of Tempranillo grapes at different stages of ripening, J. Agric. Food Chem. 53 (2005) 4019-4025.

[13] V.L. Singleton, E. Trousdale, Anthocyanin-tannin interactions explaining differences in polymeric phenols between white and red wines, Am. J. Enol. Vitic. 43 (1992) 63-70.

[14] C. Mane, N. Sommerer, T. Yalcin, V. Cheynier, R.B. Cole, H. Fulcrand, Assessment of the molecular weight distribution of tannin fractions through MALDI-TOF MS analysis of protein-tannin complexes, Anal. Chem. 79 (2007) 2239-2248.

[15] J.M. Souquet, F. Veran, C. Mane, V. Cheynier, Optimization of extraction conditions on phenolic yields from the different parts of grape clusters - Quantitative distribution of their proanthocyanidins. XXIII International Conference on Polyphenols. Winnipeg, Manitoba, Canada, 2006.

[16] P. Ribereau-Gayon, Y. Glories, A. Maujean, D. Dubourdieu, Handbook of Enology, vol. 2, The Chemistry of Wine Stabilization and Treatments, John Willey \& sons LTD, New York, 1999, pp. 129-187.

[17] J.X. Castillo-Sanchez, M.S. Garcia-Falco, J. Garrido, E. Martinez-Carballoe, L.R. Martins-Dias, C. Mejutox. Phenolic compounds and colour stability of Vinhao wines: Influence of wine-making protocol and fining agents, Food Chem. 106 (2008) 18-26.

[18] S. Stanković, S. Jović, J. Živković, Bentonite and gelatine impact on the young red wine coloured matter, Food Tech. Biotechnol. 42 (2004) 183-188.

[19] P. Sarni-Manchado, A. Deleris, S. Avallone, V. Cheynier, M. Moutounet, Analysis and characterization of wine condensed tannins precipitated by proteins used as fining agent in enology, Am. J. Enol. Vitic. 50 (1999) 81-86.

[20] C.A. Sims, J.S. Eastridge, R.P. Bates, Changes in phenols, color, and sensory characteristics of Muscadine wines by pre- and post-fermentation additions of PVPP, casein, and gelatin, Am. J. Enol. Vitic. 46 (1995) 155-158.

[21] E. Gomez-Plaza, R. Gil-Munoz, J.M. Lopez-Roca, A. Martinez-Cutillas, Color and phenolic compounds of a young red wine. Influence of wine-making techniques, storage temperature, and length of storage time, J. Agric. Food Chem. 48 (2000) 736-741.

[22] V. Kovač, E. Alonso, E. Revilla, The effects of adding supplementary seeds during fermentation on the phenolic composition of wines, Am. J. Enol. Vitic. 46 (1995) 363-367.

[23] E. Revilla, J.M. Ryan, V. Kovač, J. Nemanic, The effect of the addition of supplementary seeds and skins during fermentation on the chemical and sensory characteristics of red wines, Food Flavors: Formation, Analysis and Packaging Influences, Dev. Food Sci. 40 (1998) 583-596.

[24] V.L. Singleton, R. Orhofer, R.M. Lamuela-Raventos, Analysis of total phenols and other oxidation substrates and antioxidants by means of Folin-Ciocalteu reagent, Methods Enzymol. 299 (1999) 152-178.

[25] Y. Glories, La coleur des vins rouges, 2 Partie, Mesure, origine et interpretation, Conn. Vigne Vin. 18 (1984) 253-273.

[26] C.J. Rivas-Gonzalo, Y. Gutierrez, E. Hebrero, C. SantosBuelga, Comparisons of methods for the determination of anthocyanins in red wines, Am. J. Enol. Vitic. 43 (1992) 210- 214.

[27] E. Revilla, E. Alonso, M. Burzeix, N. Heredia, Dosage des catéchines et des proanthocyanidols dans les vins, Bull. O.I.V. F.V. 829, 1991.

[28] E. Revilla, E. Alonso, M. Burzeix, N. Heredia, Determination of catechins and procyanidins in red wine. In: Flavors and Off-Flavors '89, G. Charalambous, Ed. Elsevier Science Publishers, Amsterdam, 1990, pp. 53-60.

[29] T. Fuleki, J.M. Ricardo Da Silva, Catechin and procyanidin composition of seeds from grape cultivars grown in Ontario, J. Agric. Food Chem. 45 (1997) 1156-1160.

[30] E. Gomez-Plaza, R. Gil-Munoz, J.M. Lopez-Roca, A. Martinez-Cutillas, J.L. Fernandez-Fernandez, Phenolic compounds and colour stability of red wines: Effect of skin maceration time, Am. J. Enol. Vitic. 52 (2001) 266-270.

[31] I. Budić-Leto, T. Lovrić, U. Vrhovšek, Influence of different maceration techniques and ageing on proanthocyanidins and anthocyanins of red wine cv. Babić (Vitis vinifera L.), Food Tech. Biotechnol. 41(4) (2003) 299-303 .

[32] R.B. Boulton, The copigmentation of anthocyanins and its role in the color of red wine: A critical review, Am. J. Enol. Vitic. 52 (2001) 67-87.

[33] I. Radić, V. Puškaš, Uticaj sredstava za bistrenje na boju crnih vina, Zbornik radova sa VI savetovanja industrije alkoholnih i bezalkoholnih pića i sirćeta, Vrnjačka banja, 2002, pp. 119-122.

[34] J.J. Castillo-Sanchez, J.C. Mejuto, J. Garrido, S. GarciaFalcon, Influence of wine-making protocol and fining agents on the evolution of the anthocyanin content, colour and general organoleptic quality of Vinhao wines, Food Chem. 97 (2006) 130-136. 


\section{IZVOD}

\section{UTICAJ POSTUPKA BISTRENJA NA FENOLNE MATERIJE I BOJU CRVENIH VINA DOBIJENIH UZ DODATAK POVEĆANIH KOLIČINA ČVRSTE FAZE GROŽĐA U KLUK}

Vladimir S. Puškaš, Uroš D. Miljić

Univerzitet u Novom Sadu, Tehnološki fakultet, Novi Sad, Srbija

(Naučni rad)

Svrha ovog rada je da se ispita uticaj povećanog sadržaja šepurine i semenki u kljuku na sadržaj fenolnih materija i stabilnost boje dobijenih crvenih vina, pre $i$ nakon upotrebe različitih sredstava za bistrenje. Prilikom proizvodnje svih eksperimentalnih uzoraka vina, faza maceracije je trajala šest i devet dana. Iz dobijenih rezultata se može zapaziti povećanje sadržaja ukupnih fenola i flavan-3-ola nakon dodatka čvrstih delova grozda. S druge strane, smanjenje sadržaja antocijana je uglavnom zapaženo u svim uzorcima vina, osim u vinima proizvedenim sa dodatkom 40 g/l semenki u kljuk pre početka maceracije. Ova količina semenki je dovela do povećanja sadržaja antocijana. Dodatak šepurine u kljuk je doveo do smanjenja intenziteta boje dok je dodatak semenki uzrokovao porast ovog parametara. Ispitana je i upoređena upotreba četiri sredstva za bistrenje (albumin, želatin, bentonit i PVPP), pre svega, po pitanju njihovog uticaja na potencijalni efekat stabilizacije boje vina kao posledice povećanog sadržaja fenolnih jedinjenja semenki i šepurine. Obrada eksperimentalnih vina navedenim enološkim sredstvima dovela je do značajnog smanjenja sadržaja antocijana i flavan-3-ola. Ovo smanjenje je najizraženije u slučaju obrade vina proizvedenih nakon devetodnevne maceracije želatinom i PVPP-om, gde je utvrđeno smanjenje sadržaja antocijana za čak 60 i 70\%. Produžena faza maceracije prilikom proizvodnje vina je dovela do intezivnijeg smanjenja sadržaja fenolnih jedinjenja prilikom kasnije obrade sredstvima za bistrenje. Po pitanju parametara boje, postupak bistrenja je doveo do smanjenja intenziteta boje, međutim, važno je naglasiti da su dobijene vrednosti ovog parametra, nakon bistrenja, i dalje na nivou očekivanih vrednosti za crvena vina. Ova pojava se može objasniti stabilizujućim efektom povećanog sadržaja flavan-3-ola, poreklom iz čvrstih delova grozda, pre svega semenki. Dodatak šepurine nije uticao značajnije na stabilnost boje vina nakon bistrenja, pre svega usled efekta adsorbcije antocijana na šepurini.
Ključne reči: Crveno vino - Šepurina • Semenke • Bistrila • Fenolne materije • Boja 